\title{
Decentralized electricity generation from renewable sources as a chance for local economic development: a qualitative study of two pioneer regions in Germany
}

Britta Klagge ${ }^{*}$ and Tobias Brocke

\begin{abstract}
Background: Empirical research on the local economic effects associated with decentralized electricity generation from renewable sources has only just started. So far, most studies focus on quantifying economic effects and neglect the conditions and constellations which support and enable local economic development based on decentralized electricity generation. This, however, is the focus of this paper which looks at these issues, employing the value chain concept in combination with a governance perspective.

Methods: Empirically, we take a qualitative approach and analyze two case studies of pioneer regions, in which decentralized electricity generation from renewable sources has developed very dynamically. The case study regions are Soltau, with a special focus on biogas production, and Emden, where wind energy plays a special role. Based on the early activities of some pioneers, these regions have developed specific actor constellations and organizational structures and have entered development paths in which renewable energies became an important economic factor.

Results: The analysis highlights the importance of institutional context and supportive governance structures for an early advancement of decentralized electricity generation from renewable sources, with a key role of local actors and governance constellations. It also points to the importance of cooperative relationships among local business actors for creating a competitive advantage for (some) regional firms.

Conclusions: Our analysis shows that with the geographical proliferation of electricity generation from renewable sources, specialized firms tend to reach beyond their regions, thus offering first-mover advantages for firms in pioneer regions in comparison with latecomers.
\end{abstract}

Keywords: electricity generation, renewable energies, economic effects, governance, local economic development

\section{Background}

With the change of German energy and environmental politics, decentralized electricity generation has grown of importance especially since the 1990s [1-3]. A major part of decentralized electricity generation is achieved from renewable sources and is mainly located in rural regions. This is especially the case for biogas and wind technologies, whereas renewable electricity generation in urban areas, so far, is mainly restricted to solar,

\footnotetext{
* Correspondence: bklagge@uos.de

Institute of Geography, University of Osnabrück, Seminarstraße 19ab, Osnabrück, 49076, Germany
}

especially photovoltaic, technologies and combined heat and power plants [CHP] using biomass [4]. Whereas the planning processes and conflicts surrounding renewable energies and decentralized electricity generation have been an important topic for field research for some time, empirical research on the economic effects associated with decentralized electricity generation at the local level has only just started.

Several analyses provide evidence of the economic effects of renewable energies in quantitative terms. With renewable energies accounting for $17 \%$ of electricity generation in Germany in 2010, investment in 
equipment and total demand related to renewable energies have risen to more than $€ 26$ billion and to roughly $€ 35$ billion, respectively. Associated with this, the number of jobs in the renewable energy sector in Germany has more than doubled within 5 years and is now well beyond 370,000 [5-7]. Many of these jobs, and also a large part of the renewable energy added value, are tied to decentralized localities of electricity generation $[1,8-10]$. It is against this background that economic effects have become a major argument in favor of wind parks, biogas fermenters, and other renewable energy plants at the local level.

Conceptual thinking on this issue is generally based on value chain and actor-oriented approaches and mainly serves to highlight the opportunities and what needs to be done to capture the benefits associated with decentralized electricity generation at the local level $[8,9,11]$. In addition, various studies have set out to analyze and quantify local economic effects of renewable energies in greater detail and thus complement the generalized calculations at the national level. In these studies, explicitly or implicitly, some type of renewable energy value chain ( $c p$. Figure 1) serves as analytical basis and also as starting point for methodological discussions on how to measure local economic effects. Empirically, most of these studies focus on certain regions, technologies, and/or renewable energy sources, and they are often policy-oriented and deal with projections or scenarios rather than existent structures. ${ }^{a}$ One of the most comprehensive studies with a rather general approach, including various renewable energy value chains and several model localities, was commissioned by the Agentur für Erneuerbare Energien [AGEE] and conducted by the Institut für Ökologische Wirtschaftsforschung [IÖW] and others.

The AGEE/IÖW study [10] provides concrete data on both value-added and employment effects of renewable electricity generation at the local level by focusing on net profits of firms, net income of employees, and taxes.

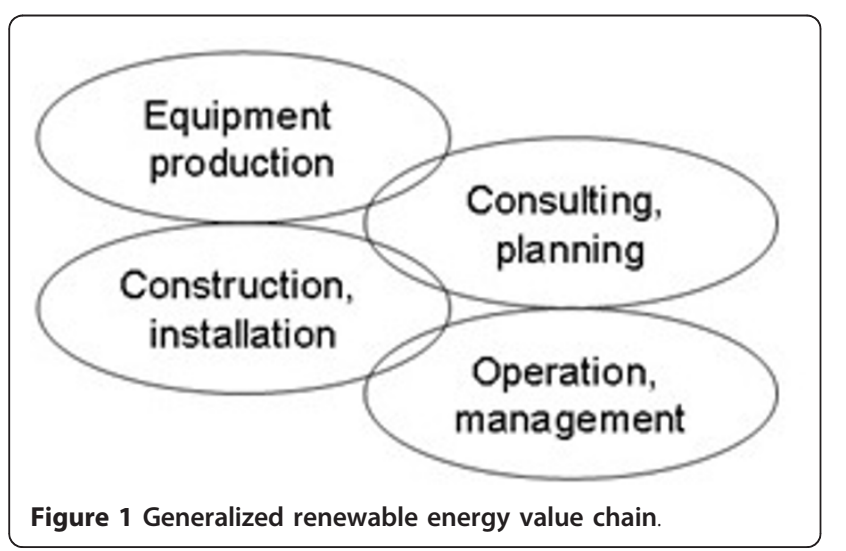

The results of this, and also of other studies (see above), clearly show the potential for local gains from renewable electricity generation. They also indicate that there are extra gains for those localities where, in addition to electricity generation itself, we find firms specialized in supplying equipment or services for renewable electricity generation, i.e., where inputs to several stages of the value chain are provided locally.

In contrast to existing studies which focus on conceptual issues or quantifying economic added value and job creation, our paper analyzes the institutional conditions and actor constellations which support and enable the development of such firms and thus local economic development based on renewable energies in two concrete case studies. Also, we do not base our research on projections or scenarios, but we take a historical case study approach. The argument we put forward is that those localities which had an early start in decentralized electricity generation from renewable sources are most likely to realize extra gains from specialized equipment or service suppliers, especially when the development has been supported by cooperative governance structures at the local level.

Governance here refers to institutions, actor constellations and their modes of coordination with respect to the organization, and (possibly) promotion of decentralized electricity generation. The focus is on both business actors directly involved in the value chain and institutional context. Business actors not only include the heterogeneous group of plant operators ${ }^{\mathrm{b}}$, but also grid operators and suppliers of equipment, services, and - in the case of biogas - raw materials. According to our governance focus, we additionally look at actors and institutions which (can) influence the development of renewable electricity generation indirectly, i.e., actors from politics, administration, and civil society, as well as institutions, in the form of laws and other formal as well as informal regulations and modes of interaction.

Actors and institutions in renewable electricity generation can be associated with different spatial levels from local to national or even international [12], thus requiring a multi-level governance perspective. The key national institution responsible for the proliferation of renewable electricity generation in Germany is the Renewable Energies Act (Erneuerbare Energien Gesetz [EEG]) from 2000, with major amendments in 2004 and 2008. It guarantees a feed-in compensation for electricity produced from renewable sources and thus provides incentives and a certain degree of security for investors. It has been heavily criticized by some as an inefficient tool to both curb greenhouse gases and generate positive economic effects [13], whereas others praise it for its positive impact on job creation and climate protection $[1,9-11,14]$. However, it is unanimously agreed that 
the EEG has been the main trigger for the fast growth of renewable electricity generation in Germany in the last decade and thus for economic effects at the local as well as other levels.

Important institutions also include planning regulations at various levels which can enable or prevent the installation and operation of renewable energy facilities in certain locations or types of locations. Next to federal and state building codes, which stipulate general rules, state and regional development plans as well as land-use plans at the local level are most important in determining favorable locations for renewable electricity generation. In addition, public-private cooperation or, more generally, the ways in which business and other actors interact at the local level are also important characteristics of governance constellations which can support local economic development based on renewable energies.

\section{Methods}

In our analysis, we take a qualitative approach with two regional case studies. As case studies, we chose two pioneer regions, in which decentralized electricity generation from renewable sources has developed very dynamically. We show that, based on the early activities of some pioneers, these regions have developed very specific organizational structures and have entered development paths in which renewable energies are now an important economic factor. The paper specifically analyzes the conditions and constellations which have supported and enabled this development. The case study regions are Soltau, with a special focus on biogas production, and Emden, where electricity generation from wind plays a special role. For the case studies which were part of a 2 -year research project on decentralized electricity generation in Northern Germany at the University of Osnabrück, in addition to the analysis of secondary data, press, and internet information, we conducted several expert interviews, mainly with local actors in the case study regions. These included representatives of utilities/grid operators, local politics and administration, civil society, plant operators, and other businesses involved in the renewable energy value chain. The interview analysis was based on suitable categories and a coding frame and was supported by the text analysis software MAXQDA (VERBI GmbH, Marburg, Germany).

\section{Case study of Emden: focus on wind energy The case study area}

The seaport city of Emden in the rural northwest of Lower Saxony has ca. 51,000 inhabitants, and it was chosen as a case study for an early implementation of decentralized electricity generation from wind. Emden exhibits one of the largest agglomerations of wind turbines in Germany and has become known for innovative wind projects. Furthermore, Emden is the location of branch plants for two large wind turbine producers. Enercon produces concrete parts in Emden which are then shipped to various sites worldwide, and BARD has a production facility for offshore turbines in Emden's port area. In addition to automobile production and port activities, the wind industry has developed into one of the most important sectors of Emden's economy [15].

There are three different distribution grid operators active in Emden. The Stadtwerke Emden GmbH [SWE] covers most of the city's area and is $100 \%$ publicly owned by the city. Lower Saxony's N-Ports is responsible for the port area; EWE NETZ GmbH, for the remaining (fringe) areas. As the port is a specific case, SWE and EWE NETZ are those grid operators relevant for decentralized electricity generation. While EWE NETZ is a pure (unbundled) grid operator and a subsidiary of the regional and fifth largest German utility EWE, SWE is an integrated utility or energy company which has both its own grid in Emden and in various power plants.

In Emden, we find both centralized and decentralized electricity generation facilities. The central facilities include a gas and a biomass plant which both feed into TenneT's (formerly EON's) transmission grid. Decentralized electricity generation in Emden uses various sources including renewable energies. At the time of analysis (2008 to 2009), 120 photovoltaic systems with a total capacity of ca. $1 \mathrm{MW}$ and several CHP using fossil fuels, as well as one sewer-gas plant, were included $[16,17]$. However, the decentralized electricity generation from wind which added up to $143 \mathrm{MW}$ from 75 turbines is the most important [18]. There are several installed turbines which are managed by farmers, but most turbines are part of four wind parks. These parks are managed by SWE, EWE, and by two specialized operating companies founded by Emden citizens and land owners, respectively, as well as by research-oriented actors and groups. The latter includes Enercon and BARD as turbine producers as well as the Arge EmdenWest, a consortium of Enercon, SWE, EWE, and a local engineering firm. Altogether, electricity generation from renewable sources (including the central biomass plant) provides roughly $100 \%$ of Emden's electricity demand. For an overview of basic information on the Emden case study in comparison with the Soltau case study, see Table 1.

\section{Actors, value-chain context, and governance structures}

The spectrum of actors involved in wind energy production in Emden is very broad and includes, among others, two utilities/grid operators (SWE, EWE/EWE NETZ) and two turbine producers (Enercon, BARD). The 
Table 1 Empirical study: overview of case studies

\begin{tabular}{|c|c|c|}
\hline Factor & City of Emden (wind energy) & City of Soltau (bioenergy) \\
\hline Area, inhabitants & $112 \mathrm{~km}^{2}, 51,292(12 / 2009)$ & $203 \mathrm{~km}^{2}, 21,856(06 / 2008)$ \\
\hline Grid operator(s) & $\begin{array}{l}\text { 1. Public utility (Stadtwerke Emden); } \\
\text { 2. Public port authority (N-Ports); and } \\
\text { 3. Private regional utility (EWE NETZ) }\end{array}$ & Only public utility (Stadtwerke Soltau) \\
\hline $\begin{array}{l}\text { Centralized } \\
\text { electricity } \\
\text { generation }\end{array}$ & 1 Gas power plant and 1 biomass power plant (wood leftovers) & 16 Wind turbines \\
\hline $\begin{array}{l}\text { Decentralized } \\
\text { electricity } \\
\text { generation } \\
\text { (installed capacity) }\end{array}$ & $\begin{array}{l}75 \text { Wind turbines (approximately } 143 \mathrm{MW} \text { installed/approved); } 120 \\
\text { photovoltaic facilities (approximately } 1 \mathrm{MW} \text { ); } 1 \text { sewer-gas plant } \\
\text { Produce, together with central biomass plant, is ca. 100\% of electricity } \\
\text { consumption in Emden }\end{array}$ & $\begin{array}{l}11 \text { Biogas plants (approximately } 10 \mathrm{MW} \text { ); fossil } \\
\text { combined heat and power plant; photovoltaic facilities } \\
\text { Produce is } 85 \% \text { of consumed power in grid area of } \\
\text { which } 68 \% \text { are from biogas plants }\end{array}$ \\
\hline Origin/pioneers & $\begin{array}{l}\text { Long tradition: } \\
\text { - Erection of first wind turbine for pumping water in the 1980s } \\
\text { - City passed formal regulation relatively early (ROP, FNP 1994) and } \\
\text { commissions public utility with installing first turbine }\end{array}$ & $\begin{array}{l}\text { Initiative of agricultural actors in the mid-1990s: } \\
\text { - Formation of a biogas working group } \\
\text { - Erection of first plants close to farms }\end{array}$ \\
\hline
\end{tabular}

Adapted from various official sources and expert interviews.

significant amount of private engagement is also very important, especially of farmers and land owners. The economic effects of electricity generation from wind in Emden, however, reach far beyond these actors. They also include consultancy and planning bureaus, firms in the construction industry, and the electrician trade, as well as others which are contracted in various stages of the value chain ( $c p$. Figure 1). A key partner for wind projects is an Emden-based engineering firm which planned and realized several Emden wind projects: 'Traditionally, [engineering firm] supports us in project development... We jointly work on new projects' (utility manager, May 2008, personal communication). Many other tasks are also sourced from local firms with the explicit aim to generate local gains. The cooperation of the various actors involved in planning and managing the wind parks is rooted in a closely knit network of local actors and is characterized by the joint implementation of innovations. Most business relations have a long history and include informal exchange and cooperation, and thus, they go far beyond purely contractrelated activities.

However, the success of Emden in the area of electricity generation from wind is not only based on the fruitful and intensive cooperation of the involved firms. In addition, the positive development has profited from the support of (semi)public and civil society actors. As in the 1980s, long before the first wind park was realized, these actors were interested in and dealt with wind energy. When a 1994 regulation of the state of Lower Saxony (Landesraumordnungsprogramm [LROP]) required the localization of wind energy preference areas in land use plans, the city of Emden established the formal institutional framework in the same year and thus paved the path for a controlled development of electricity generation from wind in its jurisdiction. In addition, the city actively supported this development politically through its leverage as $100 \%$ owner of SWE and via its local climate protection policy. Specifically, the city mandated SWE to realize Emden's first wind park; thus, it became a pioneer and major actor of decentralized electricity generation.

As chair of the supervisory board of SWE, the mayor of Emden provided the necessary political backing for the wind as well as other renewable activities of SWE. From the early 1990s, the practical side was managed by the chief executive officer [CEO] of SWE and was supported by an SWE employee who prepared the concept for the first wind park. This employee has become a key actor for wind energy development in Emden, especially after he left his job at SWE and founded the abovementioned engineering firm in 1994: 'The two of us [CEOs of utility and engineering firm] initiated this...I had the ideas, but without the support of [CEO of utility] and to some extent from the mayor, many things could not have happened' (CEO of engineering firm, March 2008, personal communication). For the engineering firm, this was the starting point of firm development, and in addition to dealing with wind (including repowering) projects in Emden and its surroundings, the firm has also ventured into planning and developing photovoltaic systems.

In summary, there were three main actors whose cooperation originally initiated and still shape the development of wind energy in Emden: first is the mayor; second is the CEO of the local utility SWE; and third is his employee and later CEO of the closely involved engineering firm. The chosen development path has thus been decisively influenced by (semi)public actors and organizations and is, to a large degree, a result of their commitment. They were bolstered by civil society and other semipublic actors. Various initiatives, including Lokale Agenda 21 and Ökowerk, have been and still are a vehicle to integrate interested individuals into the 
process. Together with the city administration and SWE who actively supported these initiatives, they have advanced the acceptance of wind energy by Emden's residents and have helped to overcome protests by nature protection activists. For a summary of the case study results in Emden (in comparison with Soltau), see Table 2.

\section{Case study of Soltau: focus on biogas production The case study area}

Soltau which is in the center of Lower Saxony was chosen as a case study because the city of Soltau as well as its surroundings exhibits a relatively high concentration of biogas plants [19]. A city of roughly 22,000 inhabitants, Soltau is located $75 \mathrm{~km}$ south of Hamburg in the Lüneburger Heide, a rural region whose economy shows a (relative) strength in agriculture and in tourism [20].

There is only one grid operator in the city of Soltau: the Stadtwerke Soltau, an integrated utility owned by the city of Soltau (50.5\%) and Stadtwerke Bremen (49.5\%) [21]. There are both centralized and decentralized electricity generation facilities. The first are 16 wind turbines with a capacity of $23.6 \mathrm{MW}$ which feed into TenneT's (formerly EON's) transmission grid. Decentralized electricity generation at the time of field research included both conventional, i.e., fossil-fueled $\mathrm{CHP}$, and electricity generation from renewable sources, namely sewer gas, wind, solar (photovoltaic), and biomass, adding up to a total electric capacity of $19 \mathrm{MW}$. In 2007, decentralized electricity generation in the city area added up to $85 \%$ of local demand with more than two thirds of this (57\% of total demand) from biomass [utility manager, March 2008, personal communication].

This electricity generation from biomass took place in 11 biogas plants with a total capacity of $10 \mathrm{MW}$ (in 2008). These plants vary in type and size, and they include three large plants with capacities of more than 1 MW each. Most plants are located on still-operating or former farmsteads in the outskirt area of Soltau; a notable exception is a large industrial plant located in an enterprise zone. Seven out of the eleven plants went into operation in 1996 and 1997, whereas the remaining ones were installed after the Renewable Energies Act (EEG) was amended in 2004. Hence, the situation today is the result of a perennial process which started in the mid-1990s. For an overview of the basic information on the Soltau case study in comparison with the Emden case study, see Table 1 .

\section{Actors, value-chain context, and governance structures}

The development of electricity generation from biogas in the Soltau region was initiated by farmers in the region, who in the mid-1990s started to build biogas fermenters on their farmsteads. In order to acquire relevant technical, biological, business, and organizational knowledge and to learn from each other, they established a biogas working group in 1995. In the context of this working group, joint activities regarding, e.g., research on and sourcing of input materials and the management of material flows were organized. These activities constituted an important basis for the development of specialized equipment and service providers in the region.

The expansion of biogas production triggered a considerable local demand for agricultural goods and services, thus providing a steady income source for farmers, machinery syndicates, and other agricultural organizations in the region. Agricultural actors actively pursued strategies to capture the value-added and employment opportunities associated with biogas production. While the provision of input materials only replaces other crop production and thus cannot count as an extra gain [10], it is different for the engagement

Table 2 Empirical study: results of case studies

\begin{tabular}{|c|c|c|}
\hline Factor & City of Emden (wind energy) & City of Soltau (bioenergy) \\
\hline Important actors & $\begin{array}{l}\text { - Stadtwerke Emden \& EWE } E^{a} \\
\text { - Private individuals, farmers }{ }^{a} \\
\text { - Turbine producers Enercon and BARD } \\
\text { - Engineering firm specialized in renewable energy } \\
\text { - Local administration and politics (active mayor) } \\
\text { - Civil society/semipublic actors }\end{array}$ & $\begin{array}{l}\text { - Farmers (as operators and/or substrate suppliers) }{ }^{\mathrm{a}, \mathrm{b}} \\
\text { - Agricultural firms } \mathrm{s}^{\mathrm{a}, \mathrm{b}} \\
\text { - Machinery syndicates } \\
\text { - Local utility: Stadtwerke Soltau } \\
\text { - Local administration }\end{array}$ \\
\hline $\begin{array}{l}\text { Types of local actors } \\
\text { involved in value creation }\end{array}$ & $\begin{array}{l}\text { - Operators and turbine producers } \\
\text { - Various service providers: consulting, planning, } \\
\text { development, and engineering firms } \\
\text { - Firms in construction, electrical installation/ } \\
\text { engineering, and other trades }\end{array}$ & $\begin{array}{l}\text { - Operators and substrate suppliers } \\
\text { - Service providers, especially in planning and development } \\
\text { - Firms in construction, electrical installation/engineering, and tank } \\
\text { and pipeline construction and maintenance }\end{array}$ \\
\hline $\begin{array}{l}\text { Characteristics of local actor } \\
\text { relationships }\end{array}$ & $\begin{array}{l}\text { - Grown structures based on long-lasting } \\
\text { cooperation } \\
\text { - Joint development and implementation of } \\
\text { innovation (with turbine producers) }\end{array}$ & $\begin{array}{l}\text { - Characterized by personal contact, stability, and trust } \\
\text { - Production structure based on division of labor among } \\
\text { operators and regional firms } \\
\text { - Network of specialized suppliers }\end{array}$ \\
\hline
\end{tabular}

${ }^{a}$ Most important operators; ${ }^{b}$ with employees directly involved in renewable energy-related business. Adapted from various expert interviews as well as official and unofficial sources. 
of machinery syndicates (Maschinenringe) in the field of managing, i.e., organizing and coordinating, and biogas production and its various material flows.

At the same time and as a reaction to the local and increasingly also national demand, nonagricultural businesses in the region were founded to serve or shifted their business focus to the needs of biogas production (e.g., in heating technology, electrical installation/engineering, motor production, and steel and container construction). Today, economic added value is generated locally at all stages of the value chain ranging from specialized equipment production and service provision over more generic construction, development, and management activities to the supply with raw materials. While some firms in the Soltau biogas scene now also serve national or even international markets, there are also strictly local employment effects, especially in the operation and management of the plants which in some cases include hiring one or more staff members.

There are differences between the plants in the degree to which certain tasks are performed internally or sourced externally from specialized suppliers. Most agricultural biogas plants are relatively small, and in addition to using own resources (including labor), personal contacts and informal arrangements with other farmers are important for securing (additional) inputs, especially raw input materials. As there is a high demand for raw materials in the Soltau region, it is an advantage to be able to make use of good relations with neighbors and colleagues and thus avoid longer transport distances and higher transport costs. In contrast with most agricultural fermenters, large and/or industrial biogas plants usually source their inputs, both materials and labor, externally and in formally fixed contracts. In addition to these structures, many operators of biogas fermenters contract the services of machinery syndicates and similar organizations as intermediators and coordinators and thus benefit from their specialized expertise and from lower transaction costs due to economies of scale.

Generally, the cooperation of plant operators with their contractors and suppliers, and also among themselves, is characterized by personal long-term and trustful relationships and cooperation, as confirmed by an operator and a supplier, respectively: 'I would never even think about changing my service suppliers. We get along well; meanwhile, we are like a club. It's always the same people' (biogas plant operator, April 2008, personal communication); 'I think the operators have great confidence in us. For example, I have a key to most of the plants and can enter them any time without talking to the operator. The trust is there, and I do not exploit it. This is really an honest story' (CEO of electrical installation firm, May 2008, personal communication).
Over the years, a network based on a longstanding division of labor and stabilized by mutual recommendation has emerged. This 'reputation network' [22] originates in the first biogas activities and cooperation of farmers in the 1990s and has gradually become larger and more diversified, which now also includes suppliers of equipment and services. In summary, the biogas scene in the Soltau region exhibits typical network characteristics which were important in developing new skills and technologies and thus enabled some specialized suppliers to serve markets beyond the Soltau region and grow into nationally or even internationally active service providers.

In contrast to Emden, (semi)public and civil society actors beyond the value chain were less crucial for the biogas development in Soltau although there is one important organization, the local (integrated) utility Stadtwerke Soltau. As grid operator, Stadtwerke Soltau is in regular contact with all plant operators and maintains stable and cooperative relationships with actors from the biogas scene. Unlike Emden, however, the local utility does not play a (pro)active role in the promotion of electricity generation from renewable energies. The same is the case for local politics and administration which have enabled the growth of biogas production in the context of their planning competences but do not actively promote renewable energies. Civil society's role is also negligible today, but this was different in the past when there was a wave of protests about odor emission which even reached the former regional government level. After this problem that originated in the utilization of a specific (cofermentation) technology was solved, protests and more generally civil society influence waned. For a summary of the case study results in Soltau (in comparison with Emden), see Table 2.

\section{Results and discussion}

\section{Emden: successful with broadly based local governance structure}

In the last decade, Emden has developed into one of the most successful locations of electricity generation from wind in Germany. This development, originally triggered by a regulation of the state of Lower Saxony (the LROP 1994), has mainly been promoted and shaped by local actors, but it would not have been possible without the favorable framework of the EEG. In the course of this development, a network of local business and other actors emerged which is characterized by close and cooperative relationships. This network includes operators of wind turbines and parks, equipment producers, utilities as well as construction, and electrician-trade and various service companies which have been working together for a long time in various projects and, in some 
cases, jointly developed and/or managed wind parks. Furthermore, a variety of additional actors that are not part of the value chain has had an impact on Emden's wind energy development. Public actors created the formal institutional framework and supported the development of semipublic and civil society initiatives. Together, (semi)public and civil society actors were important in sensitizing and convincing Emden's residents.

It is against this background that Emden developed into one of the most successful and also innovative locations for electricity generation from wind. In our opinion, this success is mainly due to the early and broadly based efforts to reconcile business, public, and other interests in a governance process at the local level. It is worth highlighting that in this governance process, public and semipublic actors, especially the mayor and SWE, played a significant role as (pro)active promoters of wind energy in Emden.

\section{Soltau: supportive local governance structure with key role for agricultural and business actors}

The electricity generation from biomass in Soltau, and also in its surroundings, was initiated by agricultural actors, namely some innovative farmers. By establishing a biogas working group and investing into biogas technology, they established the starting point for the dynamic development of biogas plants in the Soltau region since the 1990s. Today, the large number and the variety of firms in the biogas sector, both with agricultural and commercial or industrial roots, are two of the outstanding characteristics of the Soltau region and are important elements in its dynamic biogas scene.

There are various factors behind this development, but most importantly, the early local demand for biogas equipment and services in Soltau as well as a lack of specialized suppliers in this young industry more generally provided a window of opportunity for business actors in the region. The fact that this opportunity was taken has a lot to do with the cooperative network approach that characterizes Soltau's biogas development, which had its starting point in the biogas working group established by some farmers. Cooperation and trustful relationships were important for the proliferation of biogas activities in the first place and then also facilitated technical and other innovations, thus advancing the competitiveness of local firms in the biogas value chain.

In addition, a few actors that are not directly involved in the value chain have been supportive of the Soltau biogas development. This includes not only the Stadtwerke Soltau as grid operator, but also city politics and administration that have established favorable planning conditions. However, both have not played a proactive role. Public agencies in other scales or citizens and civil society organizations do not play an important role (anymore). As a whole, Soltau's biogas scene and development are characterized by a predominantly local governance context in which agricultural and other business actors play a key role, whereas political and especially civil society actors are much less important than, for example, in Emden.

\section{Conclusions}

The analysis of two pioneer regions shows that decentralized electricity generation from renewable sources can become an important factor for local economic development in rural regions and their urban centers. Associated with the expansion of decentralized electricity generation from renewable sources, source-specific (wind, biogas) local production contexts have evolved in our case study regions. In both Emden and Soltau, this includes the development of new firms as well as the specialization and/or growth of existing firms operating at various stages of the value chain. The two case studies thus provide examples of regions in which extra gains from equipment production and specialized services for the renewable energy sector are realized at the local level. Our analysis also shows that with the geographical proliferation of electricity generation from renewable sources, specialized firms and suppliers responsible for those extra gains tend to reach beyond their regions. Pioneer regions with an early dynamic development of renewable energies, such as Emden or Soltau, therefore possess first-mover advantages in comparison with latecomers if local (pioneer) firms take up the business challenges associated with renewable energies and are successful in entering not only local, but also national or even international markets.

However, while there are examples of such firms in both case study regions, this does not mean that renewable energy-related industries propel these regions forward to become the location of nationally or internationally recognized green industry clusters. ${ }^{\mathrm{c}}$ So far, most local firms involved in decentralized electricity generation remain local and only some have specialized in renewable energies only. Nonetheless, for both case study regions, the respective activities, and especially services, have become a new and steady source of local income and employment, thus diversifying their economic structure and thereby making them more resilient to economic downturns in other sectors of the economy. The analysis of our case study regions points to the importance of trustful and cooperative relationships among business actors at the local level for this development. In both regions, stable local production networks, which are characterized by such relationships, have emerged and include not only operators and their various suppliers, but also utilities. These networks 
provide a basis for sharing and jointly developing knowledge and innovations, thus creating competitive advantage for (some) firms in the value chain.

Furthermore, the two case studies also highlight the importance of institutional context and supportive governance structures for an early advancement of decentralized electricity generation from renewable sources in the first place and then for the development of local production networks. From a multi-level governance perspective, the key role of local actors and local governance constellations is, within the supportive EEG framework at the national level, especially notable. Although in the case of Emden, and wind energy more generally, regional institutions (regional planning) and multinational actors (turbine producers) are also important. The early development of renewable electricity generation in both case study regions must mainly be attributed to local actors and their initiative.

It is also noteworthy that in both case study regions individuals - from local utilities, local politics or administration (Emden), and from business or agriculture (Soltau) - played key roles in entering local development paths in which renewable energies have become an important economic factor locally. ${ }^{\mathrm{d}}$ Based on their initiatives and activities, specific organizational and institutional structures were established, which then served as a starting point for the development of local production networks. However, it is important to keep in mind that, as in other regions and countries [23-25], such developments are contingent upon public support for renewable energies at the national level, which in Germany is provided through the EEG (Renewable Energies Act).

While our case study results confirm our assumptions regarding the significance of institutional context and governance especially at the local level, the analysis of two successful pioneer regions has its limitations. It needs to be complemented by research in other types of regions as well as by geographical research on industry development. To especially confirm our argument regarding the advantages of pioneer regions, we need studies which take a long-term perspective and focus on the interaction and division of labor between producers, suppliers, and their customers in different locations both nationally and internationally.

\section{Endnotes}

${ }^{a}$ Examples are [11] on photovoltaics in the German city of Braunschweig, [26] on wind energy in the Hanover region, [27] comparing the regional value added of different bioenergy technologies based on projects in Rhineland Palatinate, and [28] with renewable energy employment scenarios for Asturia. ${ }^{\mathrm{b}}$ The most important actors are private individuals and farmers, project developers and financial service providers, industrial firms and various types of utilities [29]. ' For conceptual thinking on and examples of green industry clusters and the emergence of renewable energy industries see the works of Cooke, and Kedron and Bagchi-Sen [23-25]. ${ }^{\mathrm{d}}$ Interestingly, (actors from) the chambers of commerce as well as other business-related associations at the local or regional level are not very engaged in supporting such networks, despite the by-now obvious potential for value-added employment. Although local and regional financial service providers are involved in (credit) financing renewable electricity generation in the case study regions, they were not mentioned as important for the promotion of wind or biogas, respectively, by other actors.

\section{Abbreviations}

AGEE: Agentur für Erneuerbare Energien; CEO: chief executive officer; CHP: combined heat and power plant; EEG: Erneuerbare Energien Gesetz; IÖW: Institut für ökologische Wirtschaftsforschung; LROP:

Landesraumordungsprogramm; SWE: Stadtwerke Emden.

\section{Acknowledgements}

We thank the Ministry for Science and Culture (MWK) in Lower Saxony, Germany, which provided financial support for this research through its $\mathrm{PRO}^{*}$ Niedersachsen program, our interview partners in the two case study regions, and also the two anonymous reviewers for their helpful comments.

\section{Authors' contributions}

BK conceived the study, participated in its design, and drafted the manuscript. TB participated in the concept and design of the study and carried out the empirical research. All authors read and approved the final manuscript.

\section{Authors' information}

BK is a professor of Economic Geography and Regional Research at the University of Osnabrück. Her most recent research focuses on financial geography and energy issues. She has conceived and participated in several studies on the value chain and governance context of renewable energies as well as on the internationalization of the wind industry (for more information, see http://www.geographie.uos.de/index.php?n=Mitarbeiter. Klagge). TB is a Ph.D. student in Economic Geography at the University of Osnabrück. He conducted a study on value chain and coordination structures of decentralized electricity generation with several case studies in Northern Germany, and successfully defended his dissertation in January 2012.

\section{Competing interests}

The authors declare that they have no competing interests.

Received: 6 September 2011 Accepted: 29 February 2012

Published: 29 February 2012

\section{References}

1. AGEE (2010) Kraftwerke für jedermann. Chancen und Herausforderungen einer dezentralen erneuerbaren Energieversorgung. Agentur für erneuerbare Energien, Berlin. http://www.unendlich-viel-energie.de/uploads/media/ kraftwerke_fuer_jedermann.pdf. Accessed 18 August 2011

2. Brücher W (2009) Energiegeographie. Wechselwirkungen zwischen Ressourcen, Raum und Politik. Bornträger, Stuttgart

3. Ramesohl S, Kristof K, Fischedick M, Thomas S, Irrek W (2002) Die technische Entwicklung auf den Strom- und Gasmärkten: eine Kurzanalyse der Rolle und Entwicklungsperspektiven neuer dezentraler Energietechnologien und der Wechselwirkungen zwischen technischem Fortschritt und den Akteursstrukturen in den Strom- und Gasmärkten. Kurzexpertise für die 
Monopolkommission. Wuppertal Institut für Klima, Umwelt, Energie, Wuppertal

4. Porsche L (2010) Stadtentwicklung voller erneuerbarer Energie. Informationen zur Raumentwicklung , 9: 665-673

5. Blazejcak J, Braun FG, Edler D, Schill W-P (2011) Ökonomische Chancen und Struktureffekte einer nachhaltigen Energieversorgung. DIW Wochenbericht 20:8-15

6. BMU (2011) Beitrag erneuerbarer Energien zur Energieversorgung in Deutschland auch 2010 weiter gestiegen. 17 Prozent Anteil an der Stromversorgung, 370.000 Beschäftigte in der Branche. Pressemitteilung Nr. 039/11 (16.03.2011). Bundesministerium für Umwelt, Naturschutz und Reaktorsicherheit, Berlin. http://www.erneuerbare-energien.de/inhalt/47120/ 5466/. Accessed 18 August 2011

7. BMU (2011) Kurz- und langfristige Auswirkungen des Ausbaus der erneuerbaren Energien auf den deutschen Arbeitsmarkt. Study commissioned by the Bundesministeriums für Umwelt, Naturschutz und Reaktorsicherheit, Berlin. http://www.erneuerbare-energien.de/files/pdfs/ allgemein/application/pdf/ee_arbeitsmarkt_bf.pdf. Accessed 21 August 2011

8. BMVBS (2011) Erneuerbare Energien: Zukunftsaufgabe der Regionalplanung. Bundesministerium für Verkehr, Bau und Stadtentwicklung, Berlin. http:// www.bbsr.bund.de/cln_032/nn_21918/BBSR/DE/Neroeffentlichungen/ BMVBS/Sonderveroeffentlichungen/2011/DL_ErneuerbareEnergien, templateld=raw,property=publicationFile.pdf/DL_ErneuerbareEnergien.pdf. Accessed 18 August 2011

9. Bonow M, George W, Klement M (2009) Regionale Energieversorgung mit dezentralen und erneuerbaren Energien. Energiewirtschaftliche Tagesfragen 59(4):12-17

10. Hirschl B, Aretz A, Prahl A, Böther T, Heinbach K, Pick D, Funcke S (2010) Kommunale Wertschöpfung durch Erneuerbare Energien. Schriftenreihe des IÖW 196/10. Institut für Ökologische Wirtschaftsforschung, Berlin. http:// www.ioew.de/uploads/tx_ukioewdb/IOEW_SR_196_Kommunale_Wertsch\% C3\%B6pfung_durch_Erneuerbare_Energien.pdf. Accessed 18 August 2011

11. Hoppenbrock C, Albrecht A-K (2010) Diskussionspapier zur Erfassung "regionaler Wertschöpfung" in 100\%-EE-Regionen. Grundlagen und Anwendung am Beispiel der Fotovoltaik. Arbeitsmaterialien 100EE Nr. 3. DeENet, Kassel. http://www.100-ee.de/fileadmin/Redaktion/Downloads/ Schriftenreihe/Arbeitsmaterialien_100EE_Nr_2_2.pdf. Accessed 18 August 2011

12. George W, Bonow M, Hoppenbrock C, Moser P (2009) Regionale Energieerzeugung. Chance für eine zukunftsfähige Ziel- und Ressourcensteuerung in der Energiewirtschaft. Standort - Zeitschrift für Angewandte Geographie 33:13-21. doi:10.1007/s00548-009-0106-4.

13. Frondel M, Ritter N, Schmidt CM, Vance C (2010) Economic impacts from the promotion of renewable energy technologies: the German experience. Energy Policy 38:4048-4056. doi:10.1016/j.enpol.2010.03.029.

14. AGEE (2010) Der volle Durchblick in Sachen Erneuerbare Energien - Kosten und Nutzen. Agentur für Erneuerbare Energien, Berlin. http://www. unendlich-viel-energie.de/uploads/media/DurchblickKostenNutzen.pdf. Accessed 18 August 2011

15. NLS (2007) Niedersachsen. Das Land und seine Regionen. Land, Bezirke, Landkreise, Kreisfreie Städte. Niedersächsisches Landesamt für Statistik, Niedersächsisches Institut für Historische Regionalforschung e.V., Hannover

16. SWE (2007) EEG im Netz 2007. Leaflet handed out during an interview. Stadtwerke Emden, Emden

17. SWE (2009) Regenerative Energien. http://www.stadtwerke-emden.de/index. php?page=reg_energien. Accessed 18 May 2009

18. Stadt Emden Standorte mit Leistungsangabe von Windkraftanlagen im Stadtgebiet Emden (Stand 15.05.2008). Anfrage der Fraktion "DIE LINKE” vom 05. April 2008. Stadt Emden, Emden

19. Land Niedersachsen (2009) Biogasanlagen in Niedersachsen. Stand der Entwicklung und Perspektiven. Niedersächsisches Ministerium für Umwelt und Klimaschutz, Hannover. http://www.umwelt.niedersachsen.de/master/ C1153082_N1242216_L20_D0_1598.html. Accessed 18 August 2011

20. Rohr-Zänker R, Müller W, Fuchs O (2003) Regionales Entwicklungskonzept für den Landkreis Soltau-Fallingbostel. IES-Projektbericht 103/03. Institut für Entwicklungsplanung und Strukturforschung $\mathrm{GmbH}$ an der Universität Hannover, Hannover

21. Stadtwerke Soltau (2007) Geschäftsbericht 2006. Stadtwerke Soltau, Soltau

22. Glückler J (2004) Reputationsnetze. Zur Internationalisierung von Unternehmensberatern. Eine relationale Theorie. Transcript, Bielefeld
23. Cooke P (2010) Jacobian cluster emergence: wider insights from 'green innovation' convergence on a Schumpeterian 'failure'. In: Fornahl D, Henn S, Menzel M-P (ed) Emerging clusters. Theoretical, empirical and political perspectives in the initial stage of cluster evolution. Edward Elgar, Cheltenham, 17-42

24. Cooke P (2010) Regional innovation systems: development opportunities from the 'green turn'. Technol Anal Strateg Manage 22:831-844. doi:10.1080/09537325.2010.511156.

25. Kedron P, Bagchi-Sen S (2011) A study of the emerging renewable energy sector within lowa. Annals of the association of American Geographers 101:882-896. doi:10.1080/00045608.2011.568875.

26. Schröder A (2010) Regionalökonomische Effekte aus der Nutzung von Windenergie in der Region Hannover. Arbeitsmaterialien 100EE Nr. 3. DeENet, Kassel. http://www.100-ee.de/fileadmin/Redaktion/Downloads/ Schriftenreihe/Arbeitsmaterial_3_10-08-10.pdf. Accessed 18 August 2011

27. Hoffmann D (2009) Creation of regional value added by regional bioenergy resources. Renewable and Sustainable Energy Review 13:2419-2429. doi:10.1016/.j.rser.2009.04.001.

28. Moreno B, López AJ (2008) The effect of renewable energy on employment. The case of Asturias (Spain). Renewable and Sustainable Energy Review 12:732-751. doi:10.1016/j.rser.2006.10.011.

29. Briese D (2010) Erneuerbare Energien-Anlagen in Deutschland: Anteile einzelner Marktakteure. Energiewirtschaftliche Tagesfragen 60(8):28-30

doi:10.1186/2192-0567-2-5

Cite this article as: Klagge and Brocke: Decentralized electricity generation from renewable sources as a chance for local economic development: a qualitative study of two pioneer regions in Germany. Energy, Sustainability and Society 2012 2:5.

\section{Submit your manuscript to a SpringerOpen ${ }^{\mathcal{O}}$ journal and benefit from:}

- Convenient online submission

- Rigorous peer review

- Immediate publication on acceptance

- Open access: articles freely available online

- High visibility within the field

- Retaining the copyright to your article

Submit your next manuscript at $\gg$ springeropen.com 